\title{
Pengaruh Ekspektasi Guru terhadap Prestasi Belajar Peserta Didik Kelas VI Semester I di Madrasah Ibtidaiyah (MI) Al-Mu'awwanah Jombang
}

\author{
Eliyah $^{1}$, Imam Muttaqin ${ }^{2}$, and Aslan*3 \\ ${ }^{1}$ Institut Agama Islam Sultan Mubammad Syafiuddin sambas, Indonesia \\ ${ }^{2}$ Universitas Pesantren Tinggi Darul Ulum Jombang, Indonesia \\ ${ }^{3}$ Institut Agama Islam Sultan Mubammad Syafiuddin sambas, \\ e-mail: aslan@iaisambas.ac.id
}

Submitted: 14-01-2021 Revised : 20-02-2021 Accepted: 03-30-2021

\begin{abstract}
This study aims to dig deep information about the effect of positive and negative teacher expectations on the learning achievement of students in MI. The method used is a surveyassociative quantitative research method. The population as well as the research sample was 20 people from the teacher for variable $\mathrm{X}$ and 30 students for variable Y. Data analysis was carried out by using multiple regression analysis techniques. From the data analysis conducted, several research findings indicate that positive expectations (X1) and negative expectations (X2) simultaneously do not have a significant effect on student achievement $(\mathrm{Y})$. The strength of the relationship between Variable X1 (Teacher Positive Expectations) and X2 (Teacher Negative Expectations) simultaneously to Y (Student Learning Achievement) is $0.304=30.4 \%$ with the influence of variable X on Variable Y of $9.3 \%$ and $90,7 \%$ is influenced by variables other than the expectation variable. The regression equation that can be formed from the results of data processing is as follows: $\mathrm{Y}^{\prime}=5.310+0.006 \mathrm{X} 1-0.094 \mathrm{X} 2$. From the above equation it can be seen that the effect of positive expectations (X1) on student learning achievement (Y) is positive. This means that if teachers' positive expectations increase, the learning achievement of students will also increase. However, if the positive expectations of the teacher decrease, the learning achievement will also decrease. While the direction of the negative expectation variable (X2) on learning achievement $(\mathrm{Y})$ is negative. That is, if negative expectations increase, learning achievement will decrease. But, on the contrary, if the teacher's negative expectations decrease, the learning achievement of students will increase
\end{abstract}

Keywords: Positive Expectations, Negative Expectations, Learning Achievements

ABSTAK. Penelitian ini bertujuan utnuk menggali informasi sedalam-dalamnya tentang pengaruh ekspektasi guru baik yang positif maupun yang negatif terhadap prestasi belajar peserta didik di MI. adapun metode yagn digunakan adalah metode penelitian kuantitatif-asosiasif-survei. Populasi sekaligus sample penelitian adalah 20 orang dari guru untuk variabel $\mathrm{X}$ dan 30 orang siswa untuk variabel Y. analisi data dilakukan dengan teknik analisis regresi ganda. Dari analisis data yang dilakukan dihasilkan beberapa penemuan penelitian bahwa espektsi positif (X1) dan espektasi negatif (X2) secara simultan tidak memiliki pengaruh yang signifikan terhadap prestasi siswa (Y). Adapun kekuatan hubungan antara Variabel X1 (Ekspektasi Positif Guru) dan X2 (Ekspektasi Negatif Guru) secara bersamaan terhadap Y (Prestasi Belajar Peserta Didik) sebesar 0,304 = 30,4\% dengan pengaruh variabel $\mathrm{X}$ terhadap Variabel $\mathrm{Y}$ sebesar 9,3\% dan 90,7\% dipengaruhi oleh variabel yang lain selain variabel ekspektasi. Adapun persamaan regresi yang dapat dibentuk dari hasil pengolahan data sebagai berikut: $Y^{\prime}=5,310+0,006 \mathrm{X} 1-0,094 \mathrm{X} 2$. Dari persamaan di atas dapat dilihat bahwa pengaruh ekspektasi positif (X1) terhadap prestasi belajar peserta dididk (Y) berarah positif. Artinya jika ekspektasi positif guru semakin meningkat maka prestasi belajar peserta didik juga akan meningkat. Tapi, jika ekspektasi positif guru menurun maka preatasi belajar juga akan menurun. Sedangkan arah hubungan vriabel ekspektasi negatif (X2) terhadap prestasi 
belajar (Y) adalah negatif. Artinya, jika ekspektasi negatif meningkat maka prestasi belajar akan menurun. Tapi, sebaliknya jika ekspektasi negatif guru menurun maka prestasi belajar peserta didik akan meningkat.

Kata Kunci: Ekspektasi Positif, Ekspektasi Negatif, Prestasi Belajar

How to Cite
Eliyah, Muttaqin, I. ., \& Aslan. (2021). Pengaruh Ekspektasi Guru terhadap Prestasi Belajar Peserta Didik Kelas VI Semester I di Madrasah Ibtidaiyah (MI) Al-Mu'awwanah Jombang. Attadrib: Jurnal Pendidikan Guru Madrasab Ibtidaiyah, 4(1), 1-12.

\section{INTRODUCTION}

Espektasi adalah harapan yang tinggi seorang guru kepada siswanya, guru yakin siswanya akan sukses dan mampu belajar secara alami. (Wong \& Wong, 1999). Harapan adalah penantian yang positif. Harapan dapat meningkatkan kimia otak, meningkatkan suasana hati (mood) dan ketekunan, serta meningkatkan hasil belajar. (Jensen, 2009). Espektasi atau harapan yang tinggi ini berbeda dengan target yang tinggi. Harapan merupakan hal yang sangat kuat pengaruhnya baik bagi orang tua atau anak didik. Individu yang memiliki harapan akan berupaya lebih keras, bertahan lebih lama, dan lebih mungkin mencapai tujuan. (Wong \& Wong, 1999).

Menurut Jeanne Ellis Ormrod, ekspektasi adalah kepercayaan mengenai kemungkinan meraih kesuksesan dalam sebuah aktivitas, berdasarkan tingkat kemampuan saat ini dan kondisi eksternal yang bisa membantu atau menghambat performa. (Ormrod, 2009; Dewi \& Aslan, 2015). Ekspektasi berkaitan dengan usaha siswa dan rata-rata poin siswa di kelas. Ekspektasi guru dipengaruhi oleh penilaian guru terhadap siswa berdasarkan kondisi siswa saat ini, keluarga, etnis dan kebangsaan.

Menurut Goldenberg, Good dan Brophy, Good dan Nichols yang dikutip oleh Ormrod, (2009), penilaian guru kepada siswa dalam banyak kesempatan agak akurat: guru tahu siswa mana yang membutuhkan bantuan dalam membaca, siswa yang memiliki rentang perhatian yang pendek, dan banyak lagi serta guru juga bisa menyesuaikan pengajaran serta bantuan mereka berdasarkan identifikasi awal tersebut. (Aslan, 2016; Aslan, 2019; Aslan \& Wahyudin, 2020). Berikut beberapa pendapat ahli tentang pengaruh Espektasi pada prestasi siwa, diantaranya; Pertama, menurut Stipek, Anak-anak seperti siswa kelas satu, sangat sadar dan peka akan perlakuan yang tidak adil pada teman-temannya yang berprestasi tinggi atau rendah. Kedua, Babad, Bernier, dan Rosenthal mengatakan, sepuluh detik saja siswa melihat dan mendengar penjelasan dari guru. Siswa-siswa yang masih muda, bisa mengetahui apa yang dibicarakan gurunya. Seperti perlakuan gurunya kepada siswa yang pandai atau kepada siswa yang bodoh. Mereka juga dapat menentukan berapa besar seorang siswa dicintai oleh gurunya. Ketiga, Weinstein, harapan-harapan yang rendah yang dicerminkan dari perilaku guru menjadi ramalanramalan pemenuhan diri siswa. Perlakuan yang berbeda dari guru dapat membimbing siswa secara tidak sengaja membenarkan prediksi kemampuan mereka dengan usaha yang kurang tekun dan menghasilkan performa yang lebih buruk. (Jacob \& Furgerson, 2012). Ketiga, Rosenthl dan Jacobson, self-fulfilling prophecy mengacu kepada espektasi dan prediksi guru tentang perilaku atau prestasi siswa dan menyebabkan perilaku itu benar-benar terjadi. (Arends, 2008). Keempat, Good dan Brophy dan Oakes dan Lipton, espektasi guru melahirkan sebuah siklis perilaku baik dari pihak guru maupun siswa. Berikut gambaran siklis perilaku menurut mereka: 


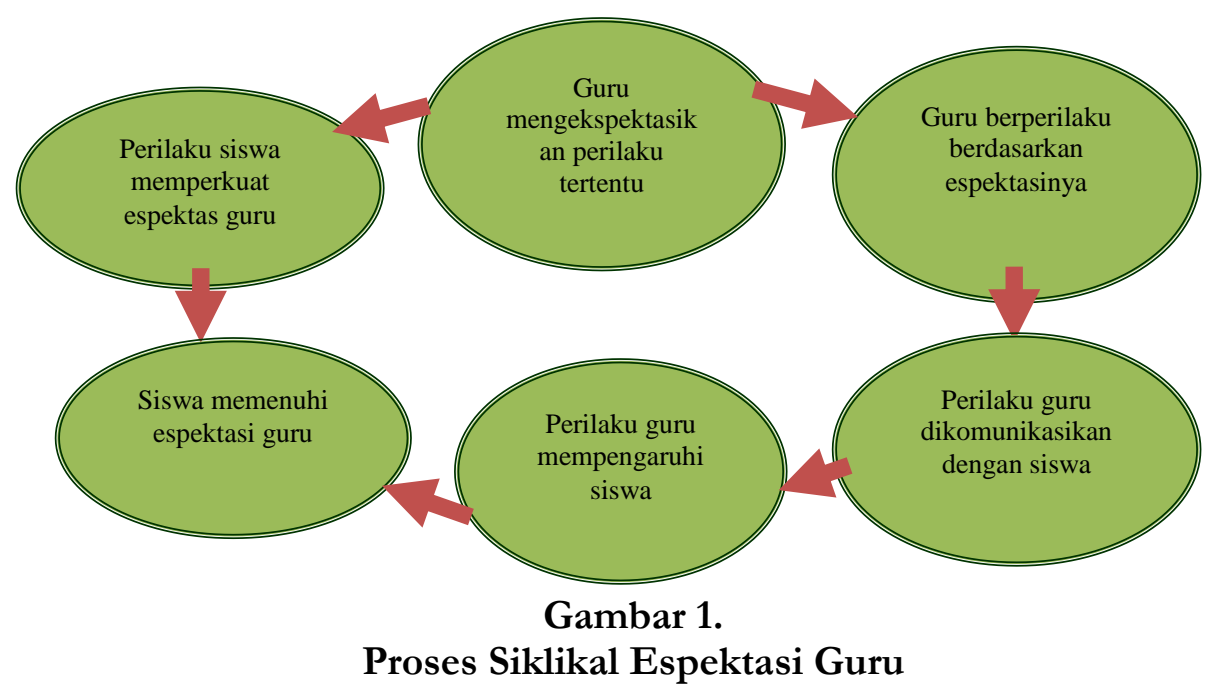

Sumber: Richard I. Arends

Perilaku yang diberikan guru kepada siswa sebagai wujud dari harapan yang diberikannya mempengaruhi harapan dan keyakinan diri serta motivasi di dalam diri siswa. Siklus perilaku ini juga sangat menentukan prestasi dan efektivitas pembelajaran di kelas. Ada dua jenis ekspektasi yaitu:

\section{Ekspektasi positif}

Espektasi posotif atau ekspektasi yang tinggi adalah sebuah keyakinan optimis bahwa siapapun mampun melakukan dan menghasilkan pencapaian dan kesuksesan. (Ormrod, 2009). Individu-individu yang memiliki ekspektasi yang tinggi akan meletakkan aktivitas-aktivitas yang membantu kesuksesannya di masa akan datang dengan benar. Guru harus memberikan alasan siswa untuk mengharapkan kesuksesan dalam tugas-tugas kelas. Keyakinan positif akan mempengaruhi tindakan dalam hal ini seorang guru terhadap siswanya.

Guru yang memiliki ekspektasi yang tinggi kepada siswa biasanya akan lebih banyak memberikan materi pelajaran dan topik-topik yang lebih sulit, lebih sering berinteraksi dengan siswa, lebih banyak menyediakan kesempatan bagi siswa untuk merespon, serta memberi umpan balik yang lebih positif dan spesifik. (Ormrod, 2009). Ada lima cara untuk mendorong harapan lebih tinggi di sekolah: (1) ceritakan kesuksesan dari tamatan yang telah lalu; (2) Berikan afirmasi positif pada siswa setiap hari; (3) bangun aset akademik dan personal anak didik, termasuk keterampilan studi dan memori; (4) anak didik diajari bagaimana menetapkan dan mencapai tujuan-selanjutnya anak didik diberikan sanjungan; dan (5) berikan anak didik visi positif yang bersifat mendorong potensi masa depan mereka. (Jensen, 2009).

\section{Ekspektasi Negatif}

Ekspektasi negatif atau ekspektasi yang rendah adalah sebuah keyakinan yang rendah bahwa siapapun yang diajar atau apapun yang dilakukan tidak akan membuahkan hasil. (Ormrod, 2009). Keyakinan positif dan keyakinan negatif ini akan mempengaruhi tindakan dalam hal ini seorang guru terhadap siswanya. Siswa juga akan menerima stimulus dari gurunya dan akan mewujudkan espektasi guru dalam bentuk perilaku. Menurut para ahli guru terbaik pun bisa melakukan kesalahan dalam menilai siswa dan mempengaruhi ekspektasi guru. Menurut mereka guru sering meremehkan kemampuan siswa seperti ciri-ciri berikut: "1. Secara fisik tidak menarik; 2 sering berperilaku tidak pantas di kelas; 3. berbicara dalam dialek selain Bahasa Ingris standar; 4. merupakan anggota kelompok monoritas ras tau etnis; 5 . merupakan imigran baru; 6 . berasal dari 
keluarga berpenghasilan rendah; dan 7. hidup dilingkungan yang lemah secara ekonomi." (Ormrod, 2009).

Guru yang memiliki ekspektasi yang rendah kepada siswa biasanya sedikit memberikan tugas sulit, mengajukan pertanyaan yang lebih mudah, menawarkan lebih sedikit kesempatan untuk berbicara di kelas, serta memberikan sedikit umpan balik tentang respon siswa. Sebagian anak-anak menyadari perilaku berbeda yang guru berikan kepada mereka, dan perbedaan perlakuan tersebut menjadi dasar bagi siswa untuk menyimpulkan kemampuan yang mereka dan orang lain miliki. (Ormrod, 2009). Apabila perlakuan yang mencerminkan guru memiliki ekspektasi yang rendah kepada siswa, maka siswa akan meyakini kemampuan mereka yang rendah. Tapi, tidak menutup kemungkinan jika perlakuan yang negatif tersebut mampu menghidupkan motivasi diri siswa untuk menunjukkan kemamapuannya, maka ekspektasi tersebut menjadi stimulus motivasi ekstrinsik.

Guru tidak selamanya benar dengan ekspektasi yang dimiliki, kadang kala guru membuat ekspektasi sepenuhnya berdasarkan informasi yang salah. Oleh karena itu sebagai guru secara khusus berhati-hatilah untuk tidak membentuk eksepktasi yang tak berdasar bagi siswa yang pada titik-titik transisi dalam karir akademik mereka. (Ormrod, 2009). Selain itu ekspektasi negatif tidak selamanya negatif. Bila guru memiliki ekspektasi negatif akan siswa dan menawarkan serta memberikan bantuan kepada siswa untuk meningkatkan kemapuannya, siswa akan menunjukkan kemapuan yang baik. Oleh karena itu yang harus guru lakukan adalah meningkatkan ekspektasi guru sebagai pendidik dan siswa sebagai pelajar.

Berikut beberapa hal yang perlu dilakukan untuk membentuk ekspektasi: 1. Ingatlah bahwa guru dapat membuat perubahan; 2. Carilah kekuatan-kekuatan pada setiap siswa; 3. Pertimbangkan berbagai kemungkinan penjelasan tentang prestasi yang rendah dan perilaku tidak pantas yang ditampilkan siswa; 4. Komunikasikan atribusi (sebab akibat kesuksesan dan kegagalan) yang optimis dan dapat dikendalikan; 5. Belajar lebih banyak tentang latar belakang dan lingkungan rumah siswa; dan 6. Nilailah kemajuan siswa secara objektif dan sering. (Ormrod, 2009).

Guru harus mengambil langkah bijak dalam menilai siswa menentukan ekspektasi yang harus diberikan. Ketika informasi berkaitan siswa telah dimiliki secara sempurna, menumbuhkan ekspektasi yang tinggi adalah lebih baik. Siswa akan meunjukkan ekspektasi gurunya adalah benar atau bisa berarti siswa akan berusaha menunjukkan bahwa ekspektasi gurunya adalah benar. Oleh karena itu, penelitian ini ingin menunjukkan apakah benar adanya terdapat pengaruh yagn signifikan anatara Ekspektasi Positif dan Negatif terhadap Prestasi Belajar Peserta didik di MI AlMuawwanah Jombang. Apakah ekspektasi positif berpengaruh positif dan ekspektasi negatif berpengaruh negatif terhadap prestasi belajar peserta didik.

\section{METHOD}

Metode yang digunakan adalah metode penelitian kuantitatif-asosiatif. Artinya, adanya hubungan atau pengaruh akibat yagn ditimbulkan variabel bebas terhadap variabel terikat. Adapun metode yang digunakan dalam mendapatkan data adalah metode survey. pada metode survey peneliti tidak memberikan sebarang perlakuan kepada responden. seingga data yang diperoleh di lapangan adalah data apa adanya tanpa ada usaha untuk memberikan perubahan perlakuan, sikap atau persepsi.

Terdapat dua variabel bebas dalam penelitian ini yaitu variabel Ekspektasi Positif (X1) dan variabek Ekspektasi Negatif (X2), serta satu variabel terikat yaitu variabel prestasi peserta didik yang dilambangkan dengan Y. Untuk mendapatkan data variabel Ekspektasi (X), peneliti menggunakan teknik non tes dengan alat pengumpul data berupa angket tertutup dengan jenis skala likert atau skala sikap. Instrumen angket untuk variabel ekspektasi yang digunakan untuk mendapatkan data telah melalui analisis validitas dan reliabilitas instrumen. Jadi, instrumen yang digunakan adalah instrumen yang valid dan reliabel. 
Tabel 1. Hasil Uji Validitas Instrumen Variabel Espektasi Positif Guru

\begin{tabular}{lcccccc}
\hline No & $\begin{array}{c}\text { Scale } \\
\text { Mean if } \\
\text { Item } \\
\text { Deleted }\end{array}$ & $\begin{array}{c}\text { Scale } \\
\text { Variance if } \\
\text { Item } \\
\text { Deleted }\end{array}$ & $\begin{array}{c}\text { Item-Total Statistics } \\
\text { Corrected } \\
\text { Item-Total } \\
\text { Correlation }\end{array}$ & $\begin{array}{c}\text { Patoka } \\
\text { Kriteria } \\
\text { Empirik } \\
\text { (Hayes, } \\
\text { X1 }\end{array}$ & $\begin{array}{c}\text { Cronbach's } \\
\text { Alpha if Item } \\
\text { Deleted }\end{array}$ & Ket \\
X11 & 40.54 & 18.936 & .620 & 0,2 & .776 & Valid \\
X1.3 & 40.54 & 18.769 & .514 & 0,2 & .783 & Valid \\
X1.4 & 40.77 & 18.359 & .500 & 0,2 & .784 & Valid \\
X1.5 & 40.92 & 16.244 & .756 & 0,2 & .752 & Valid \\
X1.6 & 41.31 & 18.397 & .446 & 0,2 & .791 & Valid \\
X1.7 & 41.46 & 15.603 & .719 & 0,2 & .755 & Valid \\
X1.8 & 40.85 & 17.141 & .650 & 0,2 & .766 & Valid \\
X1.9 & 40.54 & 20.603 & .288 & 0,2 & .803 & Valid \\
X1.10 & 40.08 & 19.744 & .598 & 0,2 & .783 & Valid \\
X1.11 & 40.08 & 21.077 & .276 & 0,2 & .804 & Valid \\
\hline
\end{tabular}

Instrumen Variabel Ekspektasi Positif yang dilanjutkan ke analisis data adalah instrumen no. $1,2,3,4,5,6,7,8,9$, dan 10 . Soal no 11 tidak valid aehingga dibuang.

Tabel 2. Hasil Uji Validitas Instrumen Variabel Espektasi Negatif Guru

\begin{tabular}{|l|r|r|r|r|r|r|}
\hline \multicolumn{7}{|c|}{ Item-Total Statistics } \\
\hline & $\begin{array}{l}\text { Scale Mean if } \\
\text { Item Deleted }\end{array}$ & $\begin{array}{c}\text { Scale Variance } \\
\text { if Item } \\
\text { Deleted }\end{array}$ & $\begin{array}{c}\text { Corrected } \\
\text { Item-Total } \\
\text { Correlation }\end{array}$ & Patokan & $\begin{array}{c}\text { Cronbach's } \\
\text { Alpha if Item } \\
\text { Deleted }\end{array}$ & Keterangan \\
\hline X2.1 & 28.08 & 9.910 & .617 & 0,200 & .432 & Valid \\
\hline X2.2 & 27.54 & 10.269 & .396 & 0,200 & .477 & Valid \\
\hline X2.3 & 27.46 & 10.603 & .336 & 0,200 & .495 & Valid \\
\hline X2.4 & 28.08 & 9.577 & .565 & 0,200 & .427 & Valid \\
\hline X2.5 & 27.85 & 10.308 & .322 & 0,200 & .495 & Valid \\
\hline X2.6 & 26.69 & 9.564 & .550 & 0,200 & .429 & Valid \\
\hline X2.7 & 27.00 & 7.000 & .744 & 0,200 & .283 & Valid \\
\hline X2.8 & 27.62 & 11.090 & .419 & 0,200 & .493 & Valid \\
\hline X2.9 & 28.92 & 17.910 &. .634 & 0,200 & .821 & Tidak Valid \\
\hline
\end{tabular}

Instrumen yang valid pada Variabel Ekspektasi Negatif adalah pada no. 1, 2, 3, 4, 5, 6, 7, dan 8. Sedangkan no. 9 dibuang karena tidak valid.

Tabel 3. Uji Reliabiltas Variabel Ekspektasi Positif Guru

\begin{tabular}{|r|r|}
\hline \multicolumn{2}{|c|}{ Reliability Statistics } \\
\hline Cronbach's Alpha & N of Items \\
\hline .844 & 10 \\
\hline
\end{tabular}

Tabel 4. Uji Reliabiltas Variabel Ekspektasi Positif Guru

\begin{tabular}{|r|r|}
\hline \multicolumn{2}{|c|}{ Reliability Statistics } \\
\hline Cronbach's Alpha & N of Items \\
\hline .821 & 8 \\
\hline
\end{tabular}


Bila dibandingkan nilai uji reliabilitas variabel X1 dan X2 dengan tabel interpretasasi koefesien kolerasi variabel berada pada kategori:

Tabel 5. Interpretasi Kategori Variabel

\begin{tabular}{lc}
\hline \multicolumn{1}{c}{ Interval Kategori } & Tingkat Pencapaian \\
\hline $\mathbf{8 0}-\mathbf{1 0 0 \%}$ & Sangat Baik \\
$\mathbf{6 0 - 7 9 , 9 \%}$ & Baik \\
$\mathbf{4 0 - 5 9 , 9 \%}$ & Cukup \\
$\mathbf{2 0}-\mathbf{3 9 , 9}$ & Rendah \\
$0-\mathbf{1 9 , 9 \%}$ & Sangat Rendah \\
\hline
\end{tabular}

Variabel Ekspektasi Positif nilai reliabilitasnya sebesar $0,844=84,4 \%$ dan Variabel Ekspektasi Negatif sebesar 0,821 $=82,1 \%$ sama-sama berada pada kategori "Sangat Baik" sehingga instrumen penelitian sangat layak.

Adapun untuk memperoleh data untuk variabel Prestasi Peserta Didik, peneliti menggunakan teknik dokumentasi. Adapun data yang diperoleh berupa file nilai raport peserta didik kelas VI semester I di MI Al-Muawwanah Jombang.

Teknik analisis data yang digunakan adalah teknik analisis regresi linier ganda. Karena, terdapat tiga variabel dalam penelitian. Sebelum analisis data dilakukan, langkah-langkah yagn dilakukan adalah: Tabulasi data, uji normalitas, uji multikolinieritas variabel X1 dan variabel X2 serta uji linieritas. Setelah semua uji [prasyarat tersebut terpenuhi dilanjutkan ke analsisi regresi ganda.

\section{HASIL DAN DISKUSI}

\section{Hasil}

Data yang dianalisis adalah data yang telah memennuhi uji prasyarat. Sebelum ke analisis regresi terlebih dahulu dipaparkan hasil uji prasayarat sebagai berikut:

\section{Uji Normalitas}

Ketentuan untuk menyimpulkan bahwa data berdistribusi normal adalah, jika nilai signifikansi pada uji normalitas 1-Sample K-S > 0,05; maka data berdistribusi normal dan sebaliknya tidak normal. Hasil uji Normalitas data untuk vriabel Ekspektasi Positif Guru (X1) dengan analisis Kolmogorov-Smirnov dapat di lihat pada tabel 4.3 di bawah:

a. Variabel Ekspektasi Positif Guru (X1)

Tabel 6. Uji Normalitas Variabel X1

\begin{tabular}{|c|c|c|}
\hline \multicolumn{3}{|c|}{ One-Sample Kolmogorov-Smirnov Test } \\
\hline & & Variabel Ekspektasi Positif Guru (X1) \\
\hline \multicolumn{2}{|l|}{$\mathrm{N}$} & 20 \\
\hline \multirow[t]{2}{*}{ Normal Parametersa,b } & Mean & 41.40 \\
\hline & Std. Deviation & 4.309 \\
\hline \multirow{3}{*}{$\begin{array}{l}\text { Most Extreme } \\
\text { Differences }\end{array}$} & Absolute & .137 \\
\hline & Positive & .137 \\
\hline & Negative & -.123 \\
\hline \multicolumn{2}{|l|}{ Test Statistic } & .137 \\
\hline \multicolumn{2}{|l|}{ Asymp. Sig. (2-tailed) } & $.200^{\mathrm{c}, \mathrm{c}}$ \\
\hline \multicolumn{3}{|c|}{ a. Test distribution is Normal. } \\
\hline \multicolumn{3}{|l|}{ b. Calculated from data. } \\
\hline \multicolumn{3}{|c|}{ c. Lilliefors Significance Correction. } \\
\hline \multicolumn{3}{|c|}{$\mathrm{d}$. This is a lower bound of the true significance. } \\
\hline
\end{tabular}


Nilai Asymp. Sig. (2-tailed) pada Tabel 6. uji normalitas untuk Variabel Ekspektasi Positif Guru (X1) sebesar 0,200 > 0,05. Artinya data berdistribusi normal.

b. Variabel Ekspektasi Negatif Guru (X2)

Tabel 7. Uji Normalitas Variabel X2

\begin{tabular}{|c|c|c|c|}
\hline \multicolumn{4}{|c|}{ One-Sample Kolmogorov-Smirnov Test } \\
\hline & & & Variabel Ekspektasi Negatif Guru \\
\hline \multicolumn{3}{|l|}{$\mathrm{N}$} & 20 \\
\hline \multirow{2}{*}{$\begin{array}{l}\text { Normal } \\
\text { Parameters } \mathrm{a}, \mathrm{b}\end{array}$} & \multicolumn{2}{|l|}{ Mean } & 30.15 \\
\hline & \multicolumn{2}{|l|}{ Std. Deviation } & 3.843 \\
\hline \multirow{3}{*}{$\begin{array}{l}\text { Most Extreme } \\
\text { Differences }\end{array}$} & \multicolumn{2}{|l|}{ Absolute } & .288 \\
\hline & \multicolumn{2}{|l|}{ Positive } & .158 \\
\hline & \multicolumn{2}{|l|}{ Negative } & -.288 \\
\hline \multicolumn{3}{|l|}{ Test Statistic } & .288 \\
\hline \multicolumn{3}{|c|}{ Asymp. Sig. (2-tailed) } & $.000^{\mathrm{c}}$ \\
\hline \multirow{3}{*}{$\begin{array}{l}\text { Monte Carlo } \\
\text { Sig. (2-tailed) }\end{array}$} & \multicolumn{2}{|l|}{ Sig. } & $.061^{\mathrm{d}}$ \\
\hline & \multirow{2}{*}{$\begin{array}{l}99 \% \text { Confidence } \\
\text { Interval }\end{array}$} & Lower Bound & .054 \\
\hline & & Upper Bound & .067 \\
\hline \multicolumn{4}{|c|}{ a. Test distribution is Normal. } \\
\hline \multicolumn{4}{|c|}{ b. Calculated from data. } \\
\hline \multicolumn{4}{|c|}{ c. Lilliefors Significance Correction. } \\
\hline \multicolumn{4}{|c|}{ d. Based on 10000 sampled tables with starting seed 2000000.} \\
\hline
\end{tabular}

Hasil uji normalitas untuk variabel Ekspektasi Negatif Guru pada Tabel 7. diperoleh nilai Monte Carlo Sig. (2-tiled) sebesar 0,061 > 0,05. Sehingga dapat disimpulkan data berdistribusi normal.

c. Uji normalitas variabel SQRTSUMY (Y)

Tabel 8. Uji Normalitas Variabel Y

\begin{tabular}{|c|c|c|c|}
\hline \multicolumn{4}{|c|}{ One-Sample Kolmogorov-Smirnov Test } \\
\hline & & & SQRTSUMY \\
\hline \multicolumn{3}{|l|}{$\mathrm{N}$} & 35 \\
\hline \multirow[t]{2}{*}{ Normal Parameters $\mathrm{a}, \mathrm{b}$} & \multicolumn{2}{|l|}{ Mean } & 25.4571 \\
\hline & \multicolumn{2}{|l|}{ Std. Deviation } & .97295 \\
\hline \multirow[t]{3}{*}{ Most Extreme Differences } & \multicolumn{2}{|l|}{ Absolute } & .169 \\
\hline & \multirow{2}{*}{\multicolumn{2}{|c|}{$\begin{array}{l}\text { Positive } \\
\text { Negative }\end{array}$}} & .109 \\
\hline & & & -.169 \\
\hline Test Statistic & \multicolumn{2}{|l|}{ Negative } & .169 \\
\hline \multicolumn{3}{|l|}{ Asymp. Sig. (2-tailed) } & $.013^{\mathrm{c}}$ \\
\hline \multirow[t]{3}{*}{ Monte Carlo Sig. (2-tailed) } & \multicolumn{2}{|l|}{ Sig. } & $.243^{\mathrm{d}}$ \\
\hline & $99 \%$ Confidence & Lower Bound & .232 \\
\hline & Interval & Upper Bound & .254 \\
\hline \multicolumn{4}{|l|}{ a. Test distribution is Normal. } \\
\hline \multicolumn{4}{|l|}{ b. Calculated from data. } \\
\hline \multicolumn{4}{|c|}{ c. Lilliefors Significance Correction. } \\
\hline d. Based on 10000 samplec & s with startin & 3525. & \\
\hline
\end{tabular}

Hasil uji normalitas variabel Prestasi Belajar Peserta Didik pada Tabel 9. dapat dilihat nilai Monte Carlo Sig. (2-tiled) sebesar 0,243 > 0,05. Artinya data berdistribusi normal.

\section{Uji Multikolonieritas Variabel X1 dan Variabel X2}

Karena variabel independent pada penelitian ini ada dua, sehingga perlu dilakukan uji multikolonieritas. Tujuannya adalah untuk memastikan bahwa tidak ada kolerasi atau hubungan antara variabel independen. (George \& Mallery, 2018). Adapun hasil yang baik adalah tidak ada kolerasi antar variabel independent. 
Tabel 9. Coefficient Correlations ${ }^{a}$

\begin{tabular}{|l|l|l|rr|}
\hline \multicolumn{2}{|c|}{ Model } & SQRTX2 & \multicolumn{2}{|c|}{$\begin{array}{c}\text { Variabel Ekspektasi } \\
\text { Positif Guru }\end{array}$} \\
\hline \multirow{4}{*}{\begin{tabular}{l} 
Correlations \\
\cline { 3 - 5 }
\end{tabular}} & SQRTX2 & 1.000 & -.555 \\
\cline { 3 - 5 } & $\begin{array}{l}\text { Variabel Ekspektasi } \\
\text { Positif Guru }\end{array}$ & -.555 & 1.000 \\
\cline { 3 - 5 } & Covariances & SQRTX2 & .005 & .000 \\
\cline { 3 - 5 } & $\begin{array}{l}\text { Variabel Ekspektasi } \\
\text { Positif Guru }\end{array}$ & .000 & $3.905 \mathrm{E}-5$ \\
\hline
\end{tabular}

Berdasarkan data pada Tabel 9. di atas, hasil kolerasi antar variabel independen sebesar 0,555 atau sekitar 55,5\% < 95\%, maka dapat dikatakana tidak terjadi multikolonieritas yang serius.

Tabel 10. Coefficients ${ }^{\mathrm{a}}$

\begin{tabular}{|c|c|c|c|c|c|c|c|c|}
\hline & & \multicolumn{2}{|c|}{$\begin{array}{l}\text { Unstandardized } \\
\text { Coefficients }\end{array}$} & \multirow{2}{*}{$\begin{array}{c}\begin{array}{c}\text { Standardized } \\
\text { Coefficients }\end{array} \\
\text { Beta }\end{array}$} & \multirow[b]{2}{*}{ t } & \multirow[b]{2}{*}{ Sig. } & \multicolumn{2}{|c|}{$\begin{array}{l}\text { Collinearity } \\
\text { Statistics }\end{array}$} \\
\hline \multicolumn{2}{|c|}{ Model } & B & Std. Error & & & & Tolerance & VIF \\
\hline \multirow[t]{3}{*}{1} & (Constant) & 5.315 & .333 & & 15.957 & .000 & & \\
\hline & $\begin{array}{l}\text { Variabel } \\
\text { Ekspektasi } \\
\text { Positif Guru }\end{array}$ & .006 & .006 & .262 & .946 & .358 & .692 & 1.446 \\
\hline & SQRTX2 & -.095 & .072 & -.362 & -1.306 & .209 & .692 & 1.446 \\
\hline
\end{tabular}

Data Tolerance yang terdapat pada Tabel 10. tidak ada variabel independen yang kurang dari 0,10. Sedangkan hasil perhitungan nilai Variance Inflation Factor (VIF) menunjukkan tidak ada satu variabel independent yang memiliki nilai VIF lebih dari 10. Sehingga dapat disimpulkan bahwa tidak ada multikolonieritas antar variabel independent dalam model regresi.

\section{Uji Linieritas}

Data dikatakan linier jika nilai probabilitas antar varibel lebih besar dari nilai probabilitas kritis 0,05 . Berikut hasil analisis antar variabel.

a. $\mathrm{X} 1$ dan $\mathrm{Y}$

Hasil output uji analisis linieritas dengan IBM SPSS 25 untuk variabel X1 dengan Y:

Tabel 11. ANOVA Table

\begin{tabular}{|c|c|c|c|c|c|c|c|}
\hline & $\begin{array}{l}\text { Sum of } \\
\text { Squares }\end{array}$ & df & $\begin{array}{l}\text { Mean } \\
\text { Square }\end{array}$ & $\mathbf{F}$ & Sig. \\
\hline \multirow{5}{*}{$\begin{array}{c}\text { Variabel } \\
\text { Prestasi Belajar } \\
* \text { Variabel } \\
\text { Ekspektasi } \\
\text { Positif Guru }\end{array}$} & \multirow{3}{*}{$\begin{array}{c}\text { Between } \\
\text { Groups }\end{array}$} & (Combined) & .087 & 11 & .008 & .684 & .727 \\
\hline & & Linearity & & 1 & .001 & .058 & .815 \\
\hline & & $\begin{array}{l}\text { Deviation from } \\
\text { Linearity }\end{array}$ & .086 & 10 & .009 & .746 & .674 \\
\hline & \multicolumn{2}{|c|}{ Within Groups } & .092 & 8 & .012 & & \\
\hline & \multicolumn{2}{|r|}{ Total } & .179 & 19 & & & \\
\hline
\end{tabular}

Berdasarkan hasil analisis linieritas di atas diperoleh nilai $\mathrm{F}$ hitung 0,746 dengan nilai probabilitas $=0,674>0,05$, berarti hubungan antara variebel X1 dan Y linier.

b. X2 dan $\mathrm{Y}$ 
Hasil output uji analisis linieritas dengan IBM SPSS 25 untuk variabel SQRTX2 dengan Y:

Tabel 12. ANOVA Table

\begin{tabular}{|l|l|l|r|r|r|r|r|}
\hline \multicolumn{2}{|c|}{} & $\begin{array}{c}\text { Sum of } \\
\text { Squares }\end{array}$ & \multicolumn{1}{c|}{$\begin{array}{c}\text { Mean } \\
\text { Df }\end{array}$} & $\begin{array}{c}\text { Square } \\
\text { Squary }\end{array}$ & \multicolumn{1}{c|}{ Sig. } \\
\hline SQRTY $*$ X2 & $\begin{array}{l}\text { Between } \\
\text { Groups }\end{array}$ & (Combined) & .082 & 8 & .010 & 1.129 & .415 \\
\cline { 2 - 8 } & Linearity & .008 & 1 & .008 & .919 & .358 \\
\cline { 2 - 8 } & $\begin{array}{l}\text { Deviation from } \\
\text { Linearity }\end{array}$ & .073 & 7 & .010 & 1.159 & .396 \\
\cline { 2 - 8 } & Within Groups & .100 & 11 & .009 & & \\
\cline { 2 - 8 } & \multicolumn{1}{|l|}{ Total } & .181 & 19 & & & \\
\hline
\end{tabular}

Data pada tabel di atas menunjukkan nilai $\mathrm{F}$ hitung sebesar 1,159 dengan nilai probabilitas sebesar 0,396 >0,05. Artinya hubungan antara variabel SQRTX2 dengan Y adalah linier. Sehingga analisis ini dapat dilanjutkan ke analisis regresi ganda.

\section{Uji Regresi}

Hasil analisis data Uji Regresi antara Variabel Ekspektasi Guru terhadap Variabel Peserta Didik sebagai berikut:

Hipotesis berbentuk kalimat:

Ha : Espektasi positif dan espektasi negatif berpengaruh secara simultan dan signifikan terhadap prestasi siswa.

H0 : Espektasi positif dan espektasi negatif tidak berpengaruh secara simultan dan signifikan terhadap prestasi siswa.

Hipotesi yagn diharapakan adalah ekspektasi potif berpengaruh positif terhadap prestasi belajar dan ekspektasi negatigf berpengaruh negatif terhadap prestasi belajar. Selanjutnya untuk mengetahui signifikansi analisis jalur dibandingkan antara nilai probalitas Sig dengan dasar pengambilan keputusan sebagai berikut:

Jika nilai probalitasnya $0,05 \leq$ nilai probalitas Sig atau $(0,05 \leq$ Sig), maka Ho ditolak, artinya tidak signifikan.

Jika nilai probalitasnya $0,05 \geq$ nilai probalitas Sig atau $(0,05 \geq$ Sig), maka Ho diterima, artinya signifikan.

Tabel 13. Model Summary

\begin{tabular}{|l|c|c|c|c|}
\hline Model & R & R Square & $\begin{array}{c}\text { Adjusted R } \\
\text { Square }\end{array}$ & $\begin{array}{c}\text { Std. Error of } \\
\text { the Estimate }\end{array}$ \\
\hline 1 & $.304^{\mathrm{a}}$ & .093 & -.014 & .09840 \\
\hline \multicolumn{3}{|l|}{$\begin{array}{l}\text { a. Predictors: (Constant), Ekspektsi Negatif Guru, Ekspektasi Positif } \\
\text { Guru }\end{array}$} \\
\hline
\end{tabular}

Adapun arti harga $\mathrm{r}$ bila dikonsultasikan dengan tabel interpretasi nilai sebagai berikut:

Tabel 14. Interpretasi koefesien Kolerasi nilai $r$

\begin{tabular}{|c|c|}
\hline Interval Koevesien & Tingkat Hubungan \\
\hline $0,80-1,00$ & Sangat kuat \\
$0,60-0,799$ & Kuat \\
$0,40-0,599$ & Cukup kuat \\
$0,20-0,399$ & Rendah \\
$0,00-0,199$ & Sangat Rendah \\
\hline
\end{tabular}


Sumber: Riduwan dan H. Sunarto

Nilai $r=0,304$ atau 30,4\% pada tabel di atas berada pada interval 0,20-0,399 pada kategori "Rendah". Sedangkan nilai $\mathrm{r}^{2}=0,093$ atau 9,3\% variabel Ekspektasi atau variabel X, baik Ekspetasi Positif (X1) dan Ekspektasi Negatif (X2) secara simultan menjelaskan variabel Prestasi Belajara (Y). Adapun 90,7 dipengaruhi oleh variabel lain di luar Ekspektasi Guru.

Tabel 15. ANOVAa

\begin{tabular}{|l|l|r|r|r|r|r|}
\hline \multicolumn{2}{|l|}{ Model } & Sum of Squares & Df & Mean Square & \multicolumn{1}{c|}{ F } & Sig. \\
\hline \multirow{3}{*}{1} & Regression & .017 & 2 & .008 & .867 & $.438^{\mathrm{b}}$ \\
\cline { 2 - 7 } & Residual & .165 & 17 & .010 & & \\
\cline { 2 - 7 } & Total & .181 & 19 & & & \\
\hline
\end{tabular}

Hasil analisis pada tabel Anova menunjukkan apakah variabel $\mathrm{X}$ dapat memprediksi variabel Y pada persamaan regresi? Karena nilai Sig: 0,438 > 0,05. Artinya variabel X pada persamaan regresi tidak dapat digunakan untuk memprediksi variabel Y.

Tabel 16. Coefficients ${ }^{a}$

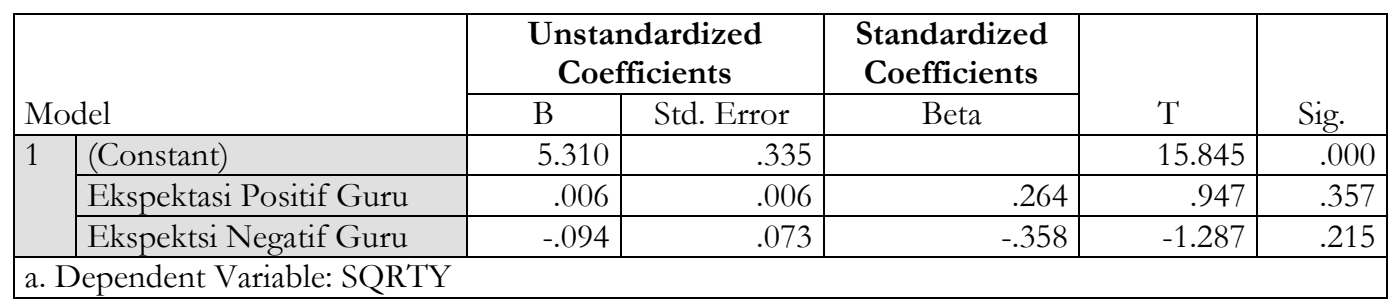

Berdasarkan hasil analisis di atas dapat dibuat persamaan regresi sebagai berikut:

$\mathrm{Y}^{\prime}=\mathrm{a}+\mathrm{bX} 1+\mathrm{bX} 2$

$\mathrm{Y}^{\prime}=5,310+0,006 \mathrm{X} 1-0,094 \mathrm{X} 2$

Dari data di atas dapat disimpulkan bahwa Variabel Ekspektasi Postif Guru memiliki arah pengaruh positif (ditunjukkan oleh lambang "+” pada koefesien X1). Artinya semakin tinggi ekspektasi positif guru maka prestasi belajar siswa akan meninggkat. Sebaliknya arah pengaruh Ekspektasi negative guru terhadap prestasi belajar siswa adalah negatif (ditunjukkan oleh lambang "_" pada koefesien X2). Artinya, semakin meningkat Ekapektasi negatif guru maka prestasi belajar peserta didik akan semakin menurut. Tapi sebaliknya semakin menurun ekspektasi negatif guru, maka prestasi belajar peserta didik akan semakin meningkat.

\section{Discussion}

Berdasarkan hasil analisis data di atas diperoleh informasi bahwa Ekspektasi Psostif memiliki pengaruh positif pada siswa. artinya semakin tinggi harapan guru kepada siswa yang ditunjukkan dengan sikap, tingkah laku, kata-kata dan emosi meberikan akan mampu meningkatkan prestasi belajar siswa. baik itu prestasi secara akademik, motivasi, kreativitas, emosi dan sosial. sedangkan ekspektasi negatif yang diperlihatkan oleh guru kepada siswa baik baik secara emosi maupun perlakuan akan memberikan efek yang buruk juga kepada kemampuan kognitif, psikomotorik dan afektif siswa. semakin buruk harapan guru, maka kabiatnya semakin buruk pula kondisi siswa.

Pengaruh positif dan negatif pada analisis data di atas dibuktikan dengan lambang $(+)$ pada koefesien variabel Ekspektasi Positif (X1) dan lambang (-) pada koefesien variabel Ekspektasi negatif pada persamaan regresi: $Y^{\prime}=5,310+0,006 \mathrm{X} 1-0,094 \mathrm{X} 2$. Berbanding lurus dengan penelitian-penelitian sebelumnya yang membahas permasalahan yang serupa: 
1. Karmita Zuriatin Asri, A. Hari Witono, dan Lalu Hamdian Affandi pada penelitian mereka, salah satu maslah penelitian mereka adalah mencari pengaruh antara ekspektasi guru terhadap hasil belajar siswa di SD Gugus V Cakranegara Tahun Pelajaran 2019/2020. Dari penelitian mereka diperoleh, bahwa ekspektasi guru memiliki pengaruh postif terhadap hasil belajar siswa. hasil tersebut ditunjukkan oleh angka positif $(+)$ pada koefesien variabel ekspektasi guru. (Asri et al., 2020).

2. Fitranty Aderestuty pada tahun 2017 dalam penelitiannya menyimpulkan bahwa Self-efficacy guru berpengaruh positip terhadap prestasi belajar siswa. (Adirestuty, 2019). Guru yang memiliki rasa percaya diri akan kemampuannya akan memberikan harapan positif kepada peserta didiknya. sheingga peserta didik akan berusaha menyesuaikan diri dengan keyakinan gurunya.

Banyak bukti lain bahwa ekspektasi positif memberikan pengaruh negatif, sebagaimana katakata positif dapat menggerakkan emosi seseorang untuk bertindak positif. harapan postif guru menjadi motivasi ekstrinsik peserta didik pada kesuksesan dirinya di masa akan datang. Pandangan orang lain pada peserta didik terutama di tingkat dasar menjadi konsep yang melekat kuat pada pikiran dan dirinya. Jika yang diterimanya adalah hal-hal negatif makan kecenderungan individu untuk melakukan hal negatif juga akan meningkat begitu juga sebaliknya.

\section{KESIMPULAN}

Dari hasil pengolahan data yang telah dilakukan, maka dihasilkan beberapa penemuan penelitian bahwa espektsi positif (X1) dan espektasi negatif (X2) secara simultan tidak memiliki pengaruh yang signifikan terhadap prestasi siswa $(\mathrm{Y})$. Adapun kekuatan hubungan antara Variabel X1 (Ekspektasi Positif Guru) dan X2 (Ekspektasi Negatif Guru) secara bersamaan terhadap Y (Prestasi Belajar Peserta Didik) sebesar 0,304 $=30,4 \%$ dengan pengaruh variabel X terhadap Variabel Y sebesar 9,3\% dan 90,7\% dipengaruhi oleh variabel yang lain selain variabel ekspektasi. Adapun persamaan regresi yang dapat dibentuk dari hasil pengolahan data sebagai berikut:

$\mathrm{Y}^{\prime}=5,310+0,006 \mathrm{X} 1-0,094 \mathrm{X} 2$

Dari persamaan di atas dapat dilihat bahwa pengaruh ekspektasi positif (X1) terhadap prestasi belajar peserta dididk (Y) berarah positif. Artinya jika ekspektasi positif guru semakin meningkat maka prestasi belajar peserta didik juga akan meningkat. Tapi, jika ekspektasi positif guru menurun maka preatasi belajar juga akan menurun. Sedangkan arah hubungan vriabel ekspektasi negatif (X2) terhadap prestasi belajar (Y) adalah negatif. Artinya, jika ekspektasi negatif meningkat maka prestasi belajar akan menurun. Tapi, sebaliknya jika ekspektasi negatif guru menurun maka prestasi belajar peserta didik akan meningkat.

\section{BIBLIOGRAPHY}

Adirestuty, F. (2019). Pengaruh Self-Efficacy Guru dan Kreativitas Guru Terhadap Motivasi Belajar Siswa dan Implikasinya Terhadap Prestasi Belajar Pada Mata Pelajaran Ekonomi. Jurnal Wabana Pendidikan, 4(1), 54-67.

Arends, R. I. (2008). Learning To Teach: Belajar untuk. Belajar Buku Satu, Terj. Helly Prajitno Soetjipto dan Sri Mulyantini Soetjipto. Pustaka Pelajar.

Aslan. (2016). Kurikulum Pendidikan Vs Kurikulum Sinetron. Khaæanah: Jurnal Studi Islam Dan Humaniora, 14(2), 135-148.

Aslan. (2019). Hidden Curriculum. Pena Indis.

Aslan \& Wahyudin. (2020). Kurikulum dalam Tantangan Perubahan. Bookies Indonesia. https://scholar.google.com/scholar?oi=bibs\&hl=en\&cluster $=17745790780728460138$ 
Asri, K. Z., Witono, H., \& Affandi, L. H. (2020). Pengaruh Ekspektasi Guru dan Self-Efficacy Siswa Terhadap Hasil Belajar Pada Siswa Kelas V di SD Gugus V Cakranegara Tahun Pelajaran 2019/2020. Pendas: Primary Education Journal, 1(1), 19-24.

Dewi, N. C. \& Aslan. (2015). Psikologi Belajar Pada Pendidikan Anak Usia Dini. Madinah: Jurnal Studi Islam, 2(1), 39-48.

George, D., \& Mallery, P. (2018). IBM SPSS Statistics 25 Step by Step: A Simple Guide and Reference. Routledge.

Hayes, A. F. (2020). Statistical Methods for Communication Science. Routledge.

Jacob, S. A., \& Furgerson, S. P. (2012). Writing interview protocols and conducting interviews: Tips for students new to the field of qualitative research. Qualitative Report, 17, 6.

Jensen, E. (2009). Guru Super dan Super Teaching: Lebih dari 100 Strategi Praktis Pengajaran Super., Terj. Benyamin Molan. PT Indeks.

Ormrod, J. E. (2009). Psikologi Pendidikan Membantu Siswa Tumbub dan Berkembang., Terj. Amitya Kumara. Er Langga.

Wong, H. K., \& Wong, R. T. (1999). The First Days of School: How to be an Effective Teacher. Harry K. Wong Publications. 